\title{
2. Encontro do Grupo de Químicos no Estrangeiro da SPQ
}

É com grande prazer que o convidamos a participar no 2..$^{\circ}$ Encontro do Grupo de Químicos no Estrangeiro da SPQ. Este evento irá decorrer virtualmente e será realizado simbolicamente na tarde do dia 10 de junho, o Dia de Portugal, de Camões e das Comunidades Portuguesas.

O encontro abrangerá temas diversos, acolhendo palestras e comunicações orais de investigadores portugueses a desempenhar as suas atividades profissionais no estrangeiro. Irá promover interações com os membros da SPQ e a comunidade química em Portugal. A inscrição é obrigatória e a participação é gratuita. Este encontro será uma grande oportunidade para estudantes de doutoramento, pós-doutorandos e jovens investigadores portugueses a trabalhar no estrangeiro

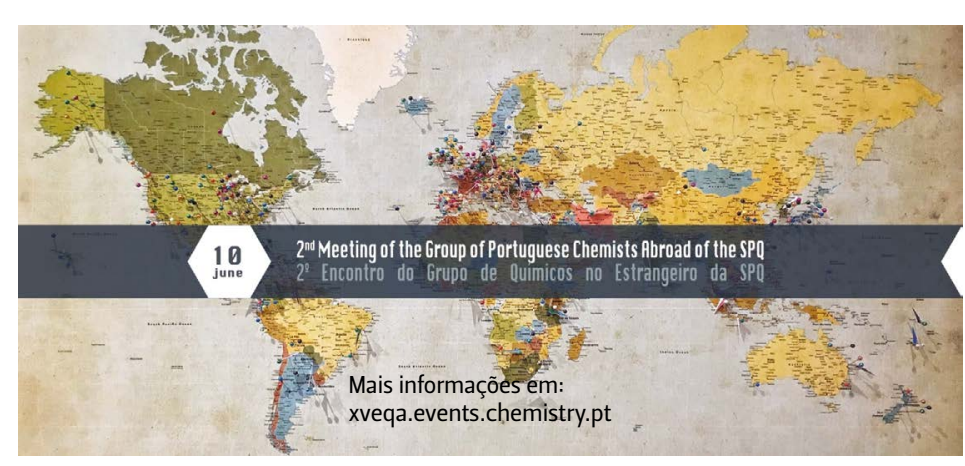

Mais informações em:

2egqe.events.chemistry.pt

\section{1. ${ }^{\circ}$ Encontro Nacional de História da Química}

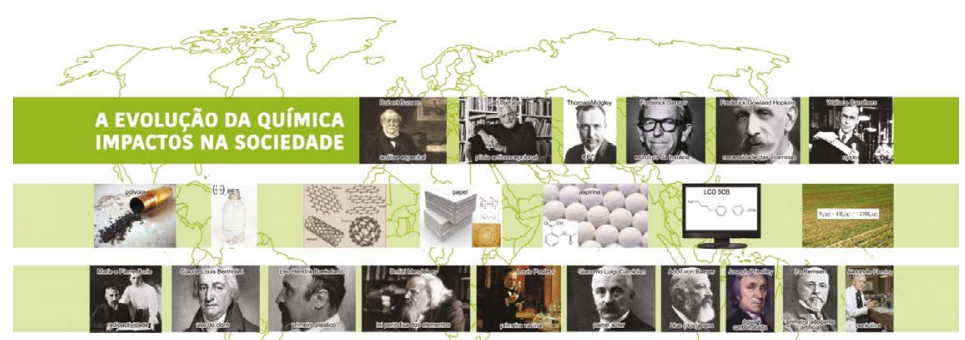

Mais informações em:

xxviienspq.events.chemistry.pt
O Encontro Nacional de História da Química realiza-se pela primeira vez, procurando agregar trabalhos de investigação desenvolvidos neste âmbito e os membros integrantes do Grupo de História da Química da Sociedade Portuguesa de Química. Deseja-se que possa ter continuidade no futuro próximo, potenciando a área de História da Ciência, Tecnologia e Medicina e constituir um fórum de pensamento crítico sobre o desenvolvimento das ciências e o seu impacto na sociedade.

O 1. ${ }^{\circ}$ Encontro Nacional de História da Química decorrerá entre os dias 17 e 18 de setembro de 2021 e irá decorrer exclusivamente em formato online via Zoom, atendendo ao momento histórico que se vive. O link será enviado aos participantes inscritos.

Está em fase de preparação a creditação deste evento para os professores inscritos que o desejem.

O envio de resumos, em português ou inglês, e seguindo os padrões do modelo disponibilizado na página do encontro, pode ser efetuado até 30 de abril de 2021. 